Veliyath and Brothers: How Emerging Market Firms Compete in Global Markets

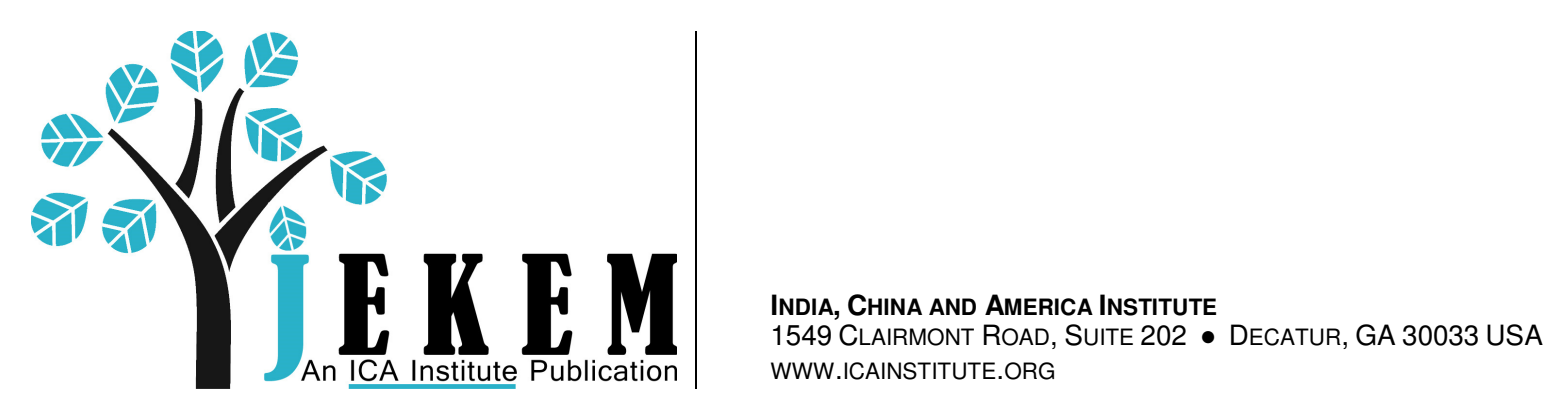

How Emerging Market firms Bompote in Global Markets

Rajaram Veliyath \& Lance Brouthers

Volume 2
November 2010

Published by DigitalCommons@Kennesaw State University, 2010 


\section{How Emerging Market Firms Compete in Glohal Markets}

Rajaram Veliyath \& Lance Brouthers Kennesaw State University

Journal of Emerging Knowledge on Emerging Markets

Volume 2

November 2010

n Emerging Market (EM) nation is a developing country whose income levels,
GDP per capita, human development indices, market institutions, technological
sophistication and production efficiencies have not reached developed country standards. However, unlike most other developing countries, Emerging Markets have sizeable domestic demand bases, rapid rates of economic growth and development, institutions capable of supporting expanding market-oriented economies, large human capital bases, and the ability to absorb and assimilate technology.

Two emerging market nations have extremely large populations. China and India have populations exceeding 1 billion each. These two countries have relatively higher GDP growth rates than countries in the developed block, as well as growth rates greater than those of the least developed countries. For example, GDP growth rates in both China and India has been averaging greater than $8 \%$ for the past 3 to 5 years.

This macro economic growth also translates into rapid market expansion rates across a range of consumer products. For example, India began with an installed base of only 30 million cell phones in 2003. At that time, given the small installed base, the Indian cell phone market did not represent a great opportunity. But subsequently the market has grown exponentially. In July 2010, the Indian mobile phone user base totaled 652 million subscribers, exceeding that of the U.S. and second in size only to that in China. With still relatively low rates of penetration, demand growth is expected to continue for the foreseeable future. This pattern has repeated itself across many market segments. Indian consumers have also shown an inclination and the ability to adopt new technologies. This is 
partly because they may have leapfrogged directly from the telegraph age to the wireless communication age, by virtue of the fact that many of them never possessed a conventional landline telephone. Because of these and many other reasons, India offers tremendous upside potential to companies across an array of industries. These market opportunities can be tapped by local home grown companies.

\section{Home Grown Emerging Market Multinational Firms}

Many Emerging Market nations have already spawned native multinational corporations, like for example, CEMEX (Mexico), companies belonging to the Tata Group, Infosys, Wipro, Bharat Forge (India), Lenovo, Haier, Huawei (China), Brahma, Embraer (Brazil), Atlas Group (Poland), and Gazprom, Lukoil, Yukos (Russia). These companies established themselves first as home grown champions in their respective countries, and then expanded internationally and globally within their respective industries. In the process, they have withstood the competitive onslaught of developed country multinationals on their home country turfs. We suggest this has been enabled by the unique context-specific advantages and capabilities they managed to cultivate in their home countries. Once established in their home country markets, each firm later expanded internationally into other developing country markets, employing these same capabilities and skill sets. After having also consolidated their positions in these developing country markets, these companies subsequently expanded into developed country markets.

We posit that contexts in emerging markets are different from developed country contexts. These contextual differences necessitate the development and deployment of unique capabilities and strategies on the parts of companies operating there. While all emerging market countries are not uniform across all of the characteristics described below, there is a great deal of commonality on these conditions within the group of emerging market countries, by virtue of their similar stages of development. Thus, companies that develop their skill sets and products/services in one emerging market are likely to more easily be able to extend them to others. Conversely, there are great differences in these characteristics in the developed group of countries. The unique characteristics of emerging markets are described below:

- Underdeveloped or inconsistent infrastructures by way of roads, power supply, clean water supply, sewer facilities, telecommunications, internet penetration.

- Tougher operating conditions for products and equipment created by the above factors as well as by heat, dust, noise, lack of sanitation and other ambient conditions.

- Underdeveloped or inefficient logistics and distribution facilities characterized by local monopolies.

- Lack of media penetration and access, especially in the interior countryside. 
- Illiterate or partially literate, sometimes unsophisticated, consumers.

- Low and inconsistent levels of income and consumer purchasing power.

- Lower levels of access to capital and to consumer credit.

- Less home storage space to purchase and store products in bulk.

- Differences in purchase habits due to cultural factors, family size and composition.

- A compelling need for new solutions to problems.

- Regulated, quasi-sheltered or untapped markets.

- Higher consumer aspirations and unmet potential demand.

In this paper, we examine the capabilities, skills, and strategies that companies from emerging markets (EMF) develop and employ while operating under these very different conditions. Further, we also trace how they utilize these unique capabilities to their advantage when they pursue international expansion, initially into other emerging markets, and later to developed country markets. These expansionary paths are very different from those undertaken by developed country multinational firms. We believe that this will enable both other emerging market companies, as well as developed country firms to learn from the experiences of these EM firms.

To begin, we examine the unique capabilities, and skills of these emerging market champions.

\section{Extendable Capability Mix for Emerging Market (EMF) Firms}

Conventional wisdom holds that firms are able to transfer their distinctive capabilities and core competencies which are primarily honed in their home country operations, globally and across country contexts. For the most part this would be true for multinational enterprises (MNE) in developed countries.

However, when entering developing country contexts, the absence of some critical supportive element or infrastructure components could nullify and render ineffective the capability or core competence that a firm has taken for granted in its developed country markets. Confronted by competitors who have developed ways of competing locally through harnessing local factor inputs, the MNE might find itself at a competitive disadvantage in these emerging market locations. For example, Dell honed its successful built-to-order model and low cost position in developed country markets. This was premised on superior inbound logistics and access to the parts needed to build its customized computers, on a just-in-time basis. Further, superior outbound logistics also ensured that the customized computer was delivered to the customer within 36 to 48 hours after final assembly. When it initially entered China in 1998, it discovered that some of the critical elements necessary for implementing its customized delivery model were lacking. 
Superior inbound logistics activity providers like dedicated local suppliers with manufacturing facilities tuned to Dell's requirements on a 24/7 basis were non-existent. Further, the outbound logistics infrastructure comprising package delivery companies who could pick up and delivery the assembled computer to the customer's premises within a one or two-day time frame were also lacking in large parts of China. Most importantly however, many customers in China were not online and could not make credit card payments. The majority of Chinese consumers were only familiar with 'cash and carry' transactions. Unlike buyers in developed countries, they were also reluctant to purchase a computer without having seen and felt it. Faced with all these contextual differences, Dell initially could not successfully transplant its developed country business model into China. It was compelled to go back to the drawing board and reexamine its strategic options.

Unique capabilities of emerging market (EM) champion firms are summarized in Table 1. Below we elaborate on these capabilities and show how some of the unique capability mixes of emerging market country MNEs (shown in Table 1) were developed in their country contexts.

\section{Table 1}

Distinctive Capability Mix of Emerging Market Firms

\begin{tabular}{|ll|}
\hline \multicolumn{1}{|c|}{ Capability or Ability } \\
\hline 1. & Ability to customize products and services \\
\hline 2. & Capability of developing business models that overcome bottlenecks \\
\hline 3. & Ability to exploit lower cost talent and factor inputs \\
\hline 4. & Ability to build and exploit economies of scale and scope \\
\hline 5. & Capability of modifying performance-to-price relationships \\
\hline 6. & Unique process innovation capabilities \\
\hline 7. & Capability to reduce complexity \\
\hline 8. & Ability to overcome negative country-of-origin perceptions \\
\hline
\end{tabular}




\section{Ability to customize products and services}

Homegrown companies have an evolved and ingrained understanding of their local markets and customers. They know customer's preferences by region, income level, age group, and gender, and strive to provide these (Bhattacharya \& Michael, 2008). For example, the low cost position in China's computer market was occupied by local computer companies like Founder, Tongfang and Legend who overcame constraints to sell computers at the then (in the mid-1990s') unbelievably low price of $\$ 360$. This was a price point that Dell was initially unable to match in the Chinese market. Some of these competitors also neutralized Dell's unique built-to-order advantages by offering the same service, at a reduced price. Similarly, global retail chains like Wal-Mart and Carrefour initially found upon entering China, that they did not have the knowledge and understanding of local customer preferences, tastes and buying habits. By contrast, Trust-Mart, a local grocery chain that owned and operated a network of neighborhood stores which stocked fresh food and grocery items preferred by neighborhood customers, had developed this knowledge base from the ground up in their different locations in China.

ITC is the Indian subsidiary of British American Tobacco. It has diversified into hotels, specialty papers, packaging, branded apparel, consumer products and food, in addition to maintaining its presence in the tobacco industry. Having operated in India for close to 100 years, it now considers itself an Indian company. In its Indian operations, ITC developed the e-Choupal (translated in Hindi as village meeting place) to ensure a steady supply of good quality soybean for its processing plants. The e-Choupal also enabled farmers in villages to collaborate and obtain fair prices for their agricultural products. Due to the lack of connectivity (i.e., telephone, cell phone, and internet) in India's rural areas, farmers did not have access to commodity prices and market conditions based on supply and demand. Therefore, there were information asymmetries between these farmers and middlemen buyers for their products, who consolidated the small purchases from many rural farmers and sold it to downstream buyers in the bigger markets (Prahalad, 2008). Because of these information asymmetries, farmers were often exploited and did not get a fair price for their products.

In order to solve this problem, ITC placed PCs with internet access in the house of the biggest farmer in each village, with the proviso that the PC could be used by and made available to all the farmers in the village on an equitable basis. With the help of the installed PC, farmers could now access and obtain real-time market information (even that from the Chicago Board of Trade) on fair prices for their products like grains, seeds, etc. This eliminated the information asymmetries that had previously existed between them and the middle-men buyers of their products (op. cit.). It also eliminated some other asymmetries like the ability to enforce contracts, and inequities in social standing between the farmer and the buyers, who were often from a higher caste. Thus, the farmer could no longer be exploited by these unscrupulous middlemen; the farmer's economic interests as well as their dignity were protected. 
The sophisticated and evolved understanding of customer tastes and preferences, product functionality and form, process requirements, as well as indigenous operating conditions, exhibited by emerging market country companies in their local markets is often extendible into other contiguous developing country markets. It succeeds in creating a bond with local customers that western MNEs find hard to duplicate. This speeds up the entry process for these EMF firms, providing them a first-mover advantage in these other emerging country markets. The well-developed, intricate knowledge base possessed by local companies is not immediately available to an MNE from a developed country entering that market for the first time. It therefore offers EMF firms a competitive advantage, albeit a temporary one, in their forays into other, proximate developing markets.

\section{Capability of developing business models that overcome bottlenecks}

Developing country markets are beset by structural problems such as lack of transportation facilities, communications infrastructure, distribution hurdles and guaranteed power supplies. Developed country MNEs which take these conditions for granted in their traditional markets, are at a loss when they find them absent when newly entering a developing market. By contrast, local champions have learned to overcome these stringencies and still operate reasonably efficiently (Bhattacharya \& Michael, 2008).

For example, Western beer companies like SAB Miller and Anheuser-Busch initially discovered that large portions of interior China's beer market did not possess the minimal infrastructure facilities like adequate paved roads, distribution trucks, a cold storage distribution chain, and storage warehouses, all things that they were used to in their traditional developed country markets. For many developed world MNEs, these infrastructural deficiencies are constraints that erode their capability bases and undermine their ability to compete.

In contrast, local companies like Tsingtao Beer Company, Beijing Beer Company and Harbin Beer had long adapted to and competed in China, in-spite of these constraints. They employed beer delivery men on bicycles who could penetrate China's interior where paved roads were often lacking, and delivered freshly brewed beer to small mom-and-mom shops in the distribution chain. Thus, beyond merely identifying the constraints, these local champions had developed methods for competing that overcame/sidestepped these obstacles. This local knowledge base and the embedded capability mix of the emerging market champions takes a long time for western MNEs to replicate.

Indian truck and car manufacturer Tata Motors has long produced vehicles with strong and rigid suspension systems that can withstand the tests and rigors of India's unpaved, rutted rural roads. These vehicles while sturdy did not incorporate state-of-the-art electronic components or systems. Therefore, they could be easily maintained and repaired by local hole-in-the-wall repair shops employing workers who did not have formal training in vehicle maintenance. Since advanced technology was not designed into the products or into the components, the availability of the necessary spare parts that might be needed for 
replacements were also not constraints. Therefore, when opportunities arose to expand into similar emerging markets, there was no pre-requisite for a sophisticated maintenance or spare parts supply infrastructure in those markets. Today, Tata Motors cars and trucks have established strong brand equity in several African developing nation markets like Tanzania, Zimbabwe, Malawi, Namibia, Mozambique, Uganda, Ghana and South Africa.

In ITC's e-Choupal example described earlier, in order for the system to work, the installed PCs however had to work under extremely arduous conditions. Voltage in the Indian power supply grid fluctuated greatly, ranging from 90 volts to 350 volts, against a rated 220 volt power supply. Power surges were frequent, resulting in equipment burn out. The supply of electricity was also unpredictable, often lasting for only 2 to 3 hours per day. In order to overcome these challenges posed by the underdeveloped operating environment, ITC engineers had to install power supply systems with solar panels that allowed uninterrupted power supply to these computers for at least 3 to 4 hours per day (Prahalad, 2008; p. 42). In addition they had to install built-in surge protectors. For communications they had to rely on the satellite network rather than on landlines, since there were none in many of the most remote villages. While increasing the system's functionality and reliability, all these modifications greatly increased costs. However, without them the system could not have operated in the hostile village environments, and the entire project would have failed (Prahalad, 2008). Most importantly, the connectivity with villages that the e-Choupal established, enabled distribution linkages for a slew of other products and services like providing weather information, education on agricultural best practices, providing customized solutions for farmers relating to fertilizers, pesticides, soil testing and seed selection (op. cit.). The e-Choupal initiative today comprises 6,500 e-Choupals transforming the lives of over 4 million farmers in 40,000 villages spread over 10 Indian States. In time, many of these innovations developed in the Indian market can be adapted for use in other emerging country markets.

This unique capability mix, often developed locally and possessed by EMF companies is an advantage. Moreover it can be extended when entering into other emerging country markets, many of which have similar infrastructural deficiencies.

\section{Ability to exploit lower cost talent and factor inputs}

Local champions develop business models that tap low-cost labor, available pools of skilled scientific and skilled manpower, or other factor inputs like raw materials. The high levels of unemployment and/or underemployment in developing countries, keeps labor costs low.

Local companies have learned from the get-go to harness and exploit this talent pool to their advantage. China's low cost manufacturing base is premised on the availability of an abundance of low cost migrant workers who have moved from a previously agrarian setting in the interior provinces to seek employment in the manufacturing sector in the more developed eastern provinces of China. 
Likewise, the initial success of India's IT sector that includes well-known companies like Infosys, Wipro and TCS, was based on exploiting India's abundance of trained programmers who worked for a fraction of Western pay levels. India has over 500000 IT engineers whose average starting salaries are $\$ 6000 /$ year. This compares with salaries more than $\$ 50000 /$ annum for a US computer science graduate.

This talent pool was initially concentrated in tier-1 cities like Bangalore, Chennai and Hyderabad. Bangalore alone had more than 150000 IT engineers, more than the total number in Silicon Valley. Of late, this talent pool has spread to tier 2 and even tier 3 Indian cities. India's homegrown IT champions have managed to keep abreast of these trends and expand into these smaller cities, where other resource constraints and infrastructure bottlenecks are even more pronounced.

Helped by the comparative wage differentials, the Chinese furniture making industry spearheaded by leaders like the Lacquer Craft Furniture Manufacturing Company and Dalian Huafeng furniture company have, since 2001, increased their share of the U.S. furniture market to more than 50\% (Engardio, 2008). Chinese wages are only 60 cents to 1.50 cents/hour including benefits, while comparable wages for the U.S. furniture industry average $\$ 16 /$ hour. As a result, labor costs account for only $6 \%$ to $8 \%$ of total production costs in China, compared to about $22 \%$ for the U.S. furniture industry (op. cit.).

The Shanghai Zhenhua Port Machinery Company (ZPMC) began to offer customized solutions for individual port operators, in addition to offering a large choice of crane models (Williamson \& Zeng, 2009). It accomplished this by tapping into China's abundant supply of low cost technical personnel. It employs 800 design engineers who help it provide these customized solutions, and today controls $54 \%$ of the global market for harbor cranes (op. cit.). The business models developed by local manufacturing or software companies in these two countries, China and India respectively, relied on exploiting these low cost (either skilled or unskilled) labor inputs. Russian aircraft manufacturing companies relied on the abundant talent pool of experienced aeronautical engineers and sophisticated designers who were rendered unemployed after the end of the Cold War and the demise of the Soviet State.

By contrast, newly entering developed country MNEs are hamstrung by existing business models that are not designed to exploit this lower cost human capital, or other available local resources. For example, many of them rely on highly automated manufacturing processes that are optimal for the high wage levels prevalent in their home country markets, but not ideal in countries with an abundant supply of employable low cost workers. These business models developed by emerging market firms which are premised on the exploitation of low cost labor or other local resources are also easily transferable to other emerging or developing country markets, which are in similar stages of economic advancement, and have similar labor pools or resource surpluses. 


\section{Ability to build and exploit Economies of Scale and Scope}

Many emerging country multinationals are fortuitously based out of nations with large domestic populations. Consequently, with time and effort, these home country markets can grow to be large enough for local champions to be guaranteed acceptable levels of economies of scale, in most industry sectors.

Thus, emerging market champion companies have the opportunity to develop economies of scale and enhance process efficiencies in sheltered, quasi-protected home country markets. Some of the newer Chinese furniture making factories of Lacquer Craft Furniture, Markoe and Shing Mark employ thousands of workers and are about the physical size of large aircraft manufacturing plants, compared to the cottage industry sized facilities of competing U.S. furniture manufacturers like Vaughan Basset (Engardio, 2008). A four million square foot Lacquer Craft factory located in Shanghai has 6 production lines (op. cit.). Such economies of scale can be huge advantages which can be exploited when entering other developing countries. Slack resources, if available in the home country, can be immediately configured to manufacture components or the complete product for other emerging country markets. Since the technological status quo in these other developing countries is likely to be comparable, very little tailoring and local adaptation of the product is necessary. For example, Lucchetti availed of the slack resources like surplus production capacity available in its home market of Chile, when it entered the branded pasta market in neighboring countries in the southern cone of Latin America.

CEMEX, a multinational cement manufacturing company from Mexico has grown to become the largest ready mix concrete company in the world with revenues approaching $\$ 22$ billion. It manufactures 96 million metric tons of cement, 80 million cubic meters of ready-to-mix concrete, 222 million metric tons of aggregates and clinker used in making cement, under different brand names. This industry is characterized by high economies of scale.

Until the mid-1990s CEMEX was able to build its scale economies and consolidate its position in a highly protected Mexican market, with little local competition. It sold both to the formal construction segment as well as to the informal or do-it-yourself segments of cement buyers in Mexico. It controls an overwhelming share of the Mexican market. With Mexico's entry into NAFTA, the barriers were removed resulting in the entry of international competition into Mexico. However by that time CEMEX had fortified its position in the Mexican market. Using this home-turf advantage, CEMEX began international expansion using acquisitions in strategic foreign markets. Today CEMEX is a global MNE employing 67000 people with operations in 50 countries and six continents. 


\section{Capability of modifying performance-to-price relationships}

Price points and affordability are much lower for the majority of an emerging market's customers. Therefore it is incumbent on companies to price their products and services at levels that local customers can afford and use. These prices may be much lower than minimally profitable price levels in developed country markets. Companies have to redesign the product and reconfigure the process from the ground up to meet these stringent specifications. This is outside of the operating philosophy of developed country MNEs who (based on the International Product Life Cycle philosophy) merely fine tune the product designs they have used for their developed country customers.

Tata Motors made the headlines by launching the Nano (the people's car) in India. The Chairman of the company realized that a typical Indian middle-class family of four (father, mother and two children) who hitherto relied on two-wheelers for transportation could be persuaded to trade up and spend a few rupees more for an affordable, safer, all-weather form of transportation. The company set out to design a vehicle from the ground up with certain parameters in mind to satisfy these target customers. Firstly, from the affordability standpoint, the price could not be more than Rupees 100,000 (i.e., slightly more than \$2000).

The car also had to comfortably seat 4 persons with generous leg space and head room for the average Indian. Providing four doors made entry and exit into the vehicle easier. The car's ground clearance had to be adequate for Indian roads. The car was designed to measure only 3.1 meters long, 1.6 meters wide and 1.6 meters high. Its unique design with wheels at the corners and the power train at the rear enabled a combination of interior space as well as maneuverability on crowded Indian city roads. The rear-wheel drive car's twocylinder, $623 \mathrm{cc}$, multi-point fuel injection gasoline engine was made of aluminum in order to reduce weight. The lean design helped minimize the car's weight and provide high fuel efficiency. With an all metal sheet body, a strong passenger compartment, and safety features such as crumple zones, intrusion-resistant doors, seat belts, strong seats and anchorages, with the rear tailgate glass bonded to the body, and turbo tires, this people's car exceeded regulatory safety requirements.

The car also exceeded regulatory environmental emission standards, with its low carbon dioxide and tailpipe emissions. Given its low price and all the included features, the car has succeeded in redrawing the performance-price curve in the Indian auto industry. Local market leaders in that segment like Maruti Suzuki Motors are scrambling to catch up. The Tatas were able to do it because they defined the constraints up-front and designed the car from the ground up to meet the targeted customers' needs and buying criteria. Given that the Nano was designed to occupy the 'sweet spot' for the Indian middle-class family of four, it is likely to be a resounding success. It is also likely to find a huge market in other emerging market nations, the profiles of whose middle-class customers are likely to be similar to India's and whose buying criteria are likely to be similar. 
Indian cell phone provider Reliance Communications introduced a mobile, multimedia phone with an up-front payment of $\$ 10$ and monthly payments of a mere $\$ 9.25$. While the low down-payment price (p) was an inducement for potential buyers (compared with the price of about $\$ 500$ for a similar phone in a developed country market), the product also provided a stunning array of services which included news, games, audio clips of movies and hit songs, video clips, astrology, numerology, city guides, TV guides, stock quotes, and internet access (Prahalad, 2008).

Each of these features increased the perceived quality $(\mathrm{q})$ of the product leading to an increased customer value (v) associated with it (where $v=q / p$ ). It is imperative to target performance-price multiple improvements of 30 to 50 times over and beyond developed market levels to be successful in emerging markets. Reliance Telecommunications has over 100 million mobile phones subscribers in India today.

Chinese appliance maker Haier sells many models of washing machines in its home market, including a small one targeted at rural customers that costs a mere \$37 (Engardio, 2008). Likewise, computer maker Lenovo manufactures simple machines costing just a couple of hundred dollars targeted at poorer rural families in China who desire to make their children computer literate (op. cit.).

Another innovation that is very popular in emerging markets like India is the single-serve package (Prahalad, 2008). Consumers in developed countries are used to buying large sized containers of a product (like cereal, detergent or shampoo). This is primarily in order to economize. In order to encourage these larger purchases, companies typically don't double the price for doubling the included quantity of a product like cereal or detergent. This causes the price/ounce for the consumer to be lower if they purchased a larger pack than with the purchase of a medium sized or a small sized pack. This motivates many buyers to buy the larger pack in order to economize, provided the product can be easily stored, it does not degrade with time, nor has short-term expiration dates associated with it.

However, many consumers in emerging markets cannot afford the higher purchase amounts for a larger quantity, because they have only a limited amount of discretionary cash flow. Moreover, for many in menial or temporary jobs like agricultural workers, delivery persons, members of street cleaning crews and construction workers, the income stream is highly unpredictable. They also have only a very limited amount of storage space in their homes. Outside of the major cities, they either do not have, or are not used to paying by credit card.

Consequently, they prefer single-serve packages of common, regularly used products, which can be used immediately, without the need to store the surplus quantities for a future occasion. This is true for a range of consumer products like detergent, soap, toothpaste, shampoo, coffee, tea, biscuits, cosmetics, spices, skin cream, matches, fruit drink concentrate, and aspirin. Without such packages, this consumer segment could not afford to purchase and consumer the item.

Thus, conventional ways of targeting markets and traditional business models excluded a wide swath of potential consumers in emerging markets from being a part of a particular 
product's customer base. In response to this problem, a number of firms in the FMCG (Fast Moving Consumer Goods) industry in the Indian market have introduced single-use packages in several of these product categories (op. cit.). This has enlarged the customer base and increased sales for these companies. This model is also an innovation that can be successfully transplanted into other emerging markets. Developed country MNEs entering emerging markets initially have neither the benefit of such insights nor the capabilities to immediately gear up to provide such innovative solutions.

\section{Unique process innovation capabilities}

The process that worked well in a developed country context may not be ideal in developing countries. There are numerous process innovations that are intended to improve the efficiency of an existing process. Over the years we have encountered Total Quality Management, Just-In-Time inventory management, Lean Manufacturing, the Toyota Production System, Six Sigma, to mention a few.

Most of these innovations target efficiency improvements in an existing process. That process has been designed for developed country environments, where the infrastructure and logistics for accessing and selling to customers exist. Customers in these developed countries also have a higher degree of environmental and societal awareness, in part stemming from their higher levels of education. Consequently, the business models prevalent in developed country markets are built around these preconditions and assumptions, many of which are taken for granted in developed country markets.

However, none of these factors are guaranteed in emerging markets. Companies have to develop innovative solutions to overcome deficiencies in logistics, infrastructure, customer awareness and customer education levels. This is the type of process innovation we refer to here.

Amul, a dairy cooperative also known as the Kaira District Co-Operative Milk Producers' Union Ltd., was started by a social worker in the Indian state of Gujarat in 1946. Amul today is organized around 13,328 cooperatives, and is today, the largest processor of raw milk in India with total sales exceeding USD1.5 billion. Amul innovated in the way in which the milk is collected from the farmers and processed. It has Automatic Milk Collection Systems installed in village milk collection centers (Prahalad, 2008; p. 31). Livestock farmers bring their daily milk collection to the village collection center. This milk is automatically measured for volume and fat content by the Milk Collection System. The farmer is paid without delay through a PC-based accounting and banking system installed for its members.

The collected milk is then transported to Maul's centralized, scale-efficient processing facilities in refrigerated vans where it is pasteurized and packaged. The milk is subsequently converted into its derivative products like butter, cheese and milk powder, as well as byproducts like pizza, and ice cream (op. cit.). 
Previously, this was a fragmented industry characterized by unwholesome, unhygienic and sometimes unethical practices. The farmers often got a raw deal for their dairy products from unscrupulous middlemen. Through its process innovation, where it co-opted the dairy farmers and co-linked their welfare with that of the milk cooperative, Amul has succeeded in making good, wholesome, unadulterated milk available, reliably and at a reasonable price, over large parts of India. Because the milk testing, weighing and payment system is fair and transparent, the farmers also now feel that they are being treated 'right'.

When ICICI, an Indian financial service provider, decided to move into retail banking in 1997, it faced entrenched banks like the State Bank of India, which had over 200 years of banking experience and had a 10,000 branch network. Instead of trying to replicate SBI's asset base and build its own branch network, ICICI built its business model on PC-based banking supplemented by a network of ATMs (Prahalad, 2008; p. 294). In addition to building its own PC and ATM based network, ICICI has also formed partnerships with large rural marketers like ITC and EID Parry to access rural farmers through their networks.

It also acquired the Bank of Madura, and Sangli Bank, both of which had large networks of rural branches that accessed rural customers in the South and West respectively. Today ICICI has over 2000 branches and an installed ATM base of over 4800 machines. ICICI has also gone international with a presence today in 18 countries. It has representative offices in the U.S., the UAE, China, Bangladesh, South Africa, Indonesia, Thailand, Singapore and Malaysia, branches in Bahrain, Belgium, Hong Kong, Sri Lanka, and Qatar, along with subsidiaries in the UK, Russia, and Canada. Many of these are emerging markets.

\section{Capability to reduce complexity}

Because the majority of the consumers in many emerging markets are not as literate, technology savvy, or sophisticated, companies in these markets need to simplify the product or in the case of service delivery, the service process, in order to make their offerings customer friendly and encourage adoption. Directly transplanting technology from the developed West with a few modifications may not be enough to entice these customers and make them lifelong clients. The product must be easy to operate, efficient, economical and sturdy enough to withstand the difficult operating conditions.

Zhongxing Medical, a Chinese company, developed a line-scan Direct Digital Radiography (DDR) machine that was ideal for the high volume radiography needs of China's hospitals (Williamson \& Zeng, 2009). By cobbling together component parts and borrowed technology from different sources, Zhongxing Medical was able to build a simple line scan DDR machine for \$20000. In addition to being ideal for standardized high volume procedures like chest scans, this DDR machine was also pegged at an ideal price point for the second and third tier of Chinese hospitals that operated on very limited budgets. Over time, Zhongxing Medical stole market share away from MNE market leaders like GE and Philips who sold their more sophisticated competing flat panel imaging machines for $\$ 150000$ to $\$ 200000$. Today Zhongxing Medical controls 50\% of the Chinese DDR market (op. cit.). 
Another example concerns the retail sector, which in many emerging markets is very fragmented. Each retail store has different portfolios of products, different terminologies and there are no set standards (Prahalad, 2008). The number of Stock Keeping Units (SKUs) might vary greatly from store to store. They might include both branded as well as unbranded products.

Therefore, in developing Point-of-Sale Systems (POS) for use in these retail stores, innovative approaches may be necessary to overcome this diversity in usage parameters. Technology based solutions such as icon-based, color-coding, voice-activated, fingerprinted and biometric iris recognition interfaces are possible solutions to the product diversity and low level of customer felicity obtaining in emerging markets (op. cit.).

TVS Electronics (a part of an Indian Business Group), spent a great deal of time researching and analyzing to determine the design parameter for a POS system. They eventually designed and introduced a POS system that included the following characteristics (Prahalad, 2008):

\section{Robustness}

Stock management capabilities

Payment modalities (cash, credit cards)

Ability to identify slow moving items

Bill printing capability in multiple languages

Back-up power supply (in case of black or brown-outs)

Handheld bar code reader

Internet enabled

Easy-to-learn and use

Economically priced

The system's adaptability and versatility enabled TVS to garner orders from a large number of end-users in a wide range of industries. It generated sales of Rupees 330 million (approximately $\$ 6.5$ million) for TVS in 2004. In response, H-P in its Indian operations developed Shop Owners Management Assistant, a simple and inexpensive device that enabled retailers to track inventories. Because of such competitive incursions, TVS soon had to introduce a newer version of the POS system into the market. In addition to its potential extendibility to other applications, TVS is likely to find a market for the system in other emerging country markets. 


\section{Ability to overcome country-of-origin perceptions}

When developing country companies enter developed country markets they have to overcome (sometimes negative) country of origin perceptions. This occurs when the popular image of the country is transferred to an individual company and its products originating from it.

In many instances, reinforced by popular media and press portrayals, developing countries have negative perceptions associated with them. For example, the negative image may have to do with poverty, disease, corruption, or crime that a country may have experienced during a recent period in its history.

Consequently, when a company from one of these developing countries attempts to enter another country market, some of these negative perceptions are associated with the company (and its product), resulting in a reluctance on the part of customers to purchase the product. Such negative factors are more likely to be present in developed country markets.

For example, one of the issues that surfaced prior to the Tata Motors purchase of marquee U.K. car companies, Jaguar and Range Rover, were the U.S. car dealers' fears that the upscale luxury image of these vehicles would be tarnished by the transfer of ownership from Ford (a first world based company) to Tata Motors (a third world based company). Thus, customers in developed countries may flinch from paying luxury car prices for cars built by emerging market companies. Such country-of-origin perceptions are unlikely to be deterrents for emerging market country multinationals, when entering other developing country markets at similar stages of development.

\section{Conclusion}

We began this study by asking the question: how can EMFs compete with western MNEs in the global marketplace? In an effort to answer this question, we examined selected EMFs that first established themselves in their home countries and then successfully expanded into global markets. We proposed that several unique strategies allowed these EMFs to create a basis for competitive advantage in their home emerging market that also allowed them to succeed in developed countries.

These strategies can be grouped into three categories: products, profitability and processes. Within the category of products we demonstrated that some EMFs have the unique advantage of understanding the conditions in which they choose to do business. By following strategies that customized their products and services and reduced complexity, EMFs make products better suited to meet the needs of their customers. This allows such EMFs to exploit markets that western MNEs will have a difficult time recognizing and addressing. As the market becomes more developed the EMFs can then follow the strategy of upgrading their products thereby overcoming negative origin-of-country perceptions. These EMFs are then positioned to expand into developed country markets as well as into other emerging markets. 


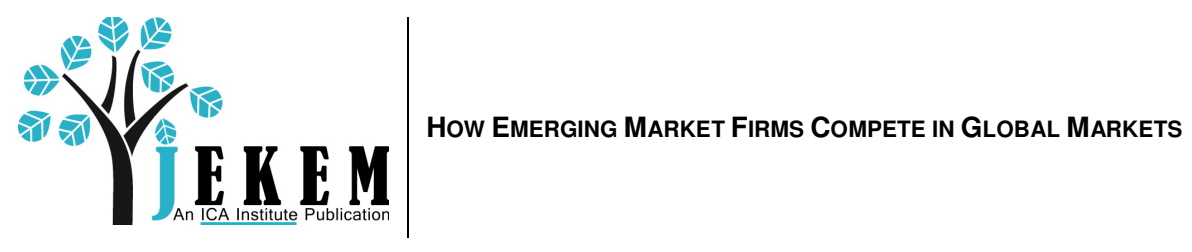

We showed that by following strategies related to profitability some EMFs can grow within their own emerging market and expand globally into other markets. These profitability strategies included capitalizing on lower cost of talent and labor, exploiting economies of scale, and modifying the typical performance-to-price relationships to better meet the needs of the emerging market.

Finally we demonstrated that certain process strategies can also be adopted. By implementing strategies that focused on developing business models that overcame bottlenecks and by identifying innovative capabilities, EMFs could capitalize on their unique skills and capabilities to overcome difficulties associated with poor infrastructure and government regulation.

We posited that once established in their home countries the EMFs were able to employ these strategies to successfully expand into other emerging markets and sometimes into developed country markets. We conclude that a different set of strategies from those typically employed by MNEs from developed countries is needed to establish a firm in emerging markets, and that some EMFs have used a combination of these strategies to expand beyond the borders of their own countries and position themselves as global competitors.

\section{Implications}

The implications for EMFs expanding into other emerging markets and into developed markets are important. When expanding into other emerging markets EMFs should utilize their experience and knowledge of emerging markets and employ these strategies. Many of the approaches the EMFs use in the home country can cross over into other emerging countries, such as is the case with the Tata Group. Tapping into and exploiting local resources, recognizing and overcoming the typical bottlenecks that occur in fractured infrastructures, and developing their products as both simple and rugged should position the EMF to enhance and accelerate establishment and growth in other emerging markets.

Similarly, when EMFs are expanding into developed country markets they should rely on their core competencies and exploit them to their advantage. The strategies discussed earlier help them to do just that. Using their dominant positions in their respective home markets, EMFs can capitalize on many of the same strategies in their expansion beyond the home market. Utilizing low cost talent, exploiting economies of scale and configuring improved price-to-performance relationships, EMFs may be able to establish themselves in developed country markets as low cost alternatives to their competitors. Once established in developed countries, EMFs can then work on expanding into higher end and more profitable products. Developing and utilizing these unique business strategies may better position EMFs as they expand globally.

For MNEs from developed countries, understanding these strategies will be critical in their bid to compete in the EMFs' home markets, other emerging markets and in the 
developed economies. As Dell discovered when entering China, many MNEs will need to modify their business model to position themselves to compete with local EMFs and obtain maximum penetration into other emerging markets. Knowing the successful strategies of successful EMFs can help MNEs eschew the mantra of bigger, faster and more complicated and focus instead on simpler, cheaper, and more rugged. As MNEs penetrate emerging markets and gain solid traction they become better positioned to exploit their core competencies (that made them successful in their home and other developed markets) as the emerging market transitions into a developed economy.

Likewise, recognizing these strategies can assist MNEs in their bid to compete with EMFs in developed economies. Understanding what strategies may be employed by EMFs, MNEs can adopt similar strategies to expand into their own and other developed economies. These include tapping into low cost talent and resources of emerging markets and using them to solidify and accelerate growth in developing economies. This strategy will also help to establish the presence of these developed country MNEs in emerging markets, thereby enabling them better access to local knowledge and expertise and positioning them to capitalize on the emerging market's future growth.

Thus, whether a company is an EMF or a more traditional MNE, knowing and implementing some or all of these eight strategies may help position the firm for penetration and growth in the global economy at large.

\section{References}

Bhattacharya, A. M., \& Michael, D.C. How Local Companies Keep Multinationals at Bay. Harvard Business Review South Asia. 2008, March, pp. 71-81.

Engardio, P. CHINDIA: How China and India are Revolutionizing Global Business. 2008. New Delhi, India: Tata-McGraw Hill Publishing Company.

Prahalad. C.K., The Fortune at the Bottom of the Pyramid. 2008, 4th Edition, New Delhi, Pearson Education and Wharton School Publishing.

Williamson, P.J., \& Zeng, M. Value-for-Money Strategies for Recessionary Times. Harvard Business Review South Asia. 2009, March, pp. 48-56. 